\title{
EFEK EKSTRAK DAUN SENDOK (Plantago major L.) TERHADAP ERITEMA PADA MARMUT PUTIH BETINA (Guinea pig) OLEH RADIASI ALAT MODIFIKASI UV 04-08
}

\author{
(EFFECTS OF SENDOK LEAF EXTRACT (Plantago major L.) ON ERITEMA ON WHITE \\ FEMALE MARMUT (Guinea pig) BY RADIATION OF UV MODIFICATION TOOL 04-08)
}

\author{
DHIANCINANTYAN WINDYDACA BRATA PUTRI ${ }^{1}$, NI PUTU ARYATI, S. ${ }^{1}$ \\ ${ }^{1}$ Program Studi Farmasi Klinis, Institut Ilmu Kesehatan Medika Persada Bali, Denpasar, Bali
}

\begin{abstract}
Abstrak: Penelitian ini bertujuan untuk mengetahui efek anti-inflamasi ekstrak daun sendok (Plantago major L.) pada hewan coba berupa marmut putih betina (Guinea pig) yang diinduksi radiasi UV-B (290-320 nm). Penelitian ini menggunakan 30 ekor marmut putih betina yang dibagi menjadi kelompok uji sebanyak 10 ekor, kelompok pembanding sebanyak 10 ekor dan kelompok kontrol sebanyak 10 ekor. Kelompok uji diberi kapsul daun sendok dengan dosis $50 \mathrm{mg} / \mathrm{kg}$ yang diberikan secara oral tiap 5 jam sekali sehari, kelompok pembanding diberi obat antalgin dengan dosis $50 \mathrm{mg} / \mathrm{kg}$ yang diberikan secara oral tiap 5 jam sekali sehari dan kelompok kontrol diberi aquadem secara oral tiap 5 jam sekali sehari. Parameter yang diamati berupa perbandingan gradasi eritema dan persentase perubahan luas area eritema setelah diinduksi radiasi UV-B dan 24 jam setelah diinduksi radiasi UV-B. Berdasarkan hasil persentase perubahan luas area eritema dan gradasi eritema dapat disimpukan bahwa ekstrak daun sendok memiliki efek anti-inflamasi, tetapi efek anti-inflamasi ekstrak daun sendok tidak sebaik efek anti-inflamasi antalgin (sebagai pembanding).
\end{abstract}

Kata kunci: anti-inflamasi, eritema, Plantago major L.

\begin{abstract}
This research was aimed to determine anti-inflammatory effect of spoon leaf extract (Plantago major L.) in female guinea pig with induced UV-B radiation $(290-320 \mathrm{~nm})$. The research used 30 female guinea pigs divided into treatment group, comparison group and control group. The treatment group was given spoon leaf capsule at $50 \mathrm{mg} / \mathrm{kg}$, the comparison group was given Antalgin at $50 \mathrm{mg} / \mathrm{kg}$, and the control group was given aquadem where each group was given orally every 5 hours for 24 hours. Parameters observed were comparisons of erythema gradient and percentage change in area of erythema after induction of UV-B radiation and 24 hours after UV-B radiation induced. Based on the result of percentage change of area of erythema and erythema gradation it can be concluded that spoon leaf extract has anti-inflammatory effect, but anti-inflammatory effect of spoon leaf extract is not as good as anti-inflammatory effect of Antalgin (as comparison).
\end{abstract}

Keywords: anti-inflammatory, erythema, Plantago major L.

\section{PENDAHULUAN}

Inflamasi merupakan suatu sistem pertahanan tubuh yang berfungsi mengembalikan tubuh pada keadaan normal akibat masuknya bahan asing ataupun trauma. Apabila reaksi inflamasi tersebut terlalu berlebihan dapat merusak jaringan-jaringan yang tidak mengalami inflamasi. Untuk mengurangi reaksi inflamasi yang terjadi, banyak digunakan pemberian obat anti-inflamasi seperti NSAID, akan tetapi efek samping dan toksisitas penggunaan obat antiinflamasi tersebut dalam jangka panjang dapat meningkat secara signifikan. WHO telah merekomendasikan penggunaan obat tradisional dalam pencegahan dan pengobatan penyakit (Gan G.S, 2003). Penggunaan obat tradisional yang diduga mempunyai efek anti-inflamasi salah satunya adalah daun sendok (Plantago major L.). Kandungan pada tanaman daun sendok yang berkhasiat sebagai anti-inflamasi adalah aukubin, catalpol, baicalein, asam klorogenat, asam salisilat, tanin, asam askorbat dan $\beta$-sitosterol, dimana kandungan tersebut terdapat pada tanaman salix alba, scutellaria baicalensis Georgi dan catalpa ovata G.Don (Calixto J.B, 2004). Tetapi data-data ilmiah tentang tanaman daun sendok sebagai anti-inflamasi belum ada, untuk itu perlu dilakukan suatu pengujian terhadap efektivitas anti-inflamasi daun sendok menggunakan metode eritema dimana sinar UV-B (290-320 nm) sebagai penginduksi radang dan untuk mengetahui besarnya efek anti-inflamasi daun sendok, maka dalam penelitian ini digunakan obat antalgin sebagai pembanding.

\footnotetext{
• email korespondensi: windydaca18@gmail.com
} 


\section{METODE PENELITIAN}

Bahan uji yang digunakan dalam penelitian ini adalah sediaan kapsul yang berisi serbuk kering daun sendok (Plantago major L.). Obat ini telah mendapatkan ijin usaha industri dari Depkes RI No. 448/1129/Kes/V/2002.

Alat-alat penunjang yang digunakan dalam penelitian ini adalah alat UV Modifikasi 04-08, alat pencukur bulu, timbangan hewan, gunting, tisue, gelas piala, pengaduk, corong, labu ukur, kertas saring, pipet tetes pendek, pipet tetes panjang, speet injeksi, pipa zonde lambung marmut dan kayu, stopwatch, loop (kaca pembesar), spidol dan penggaris.

Variabel yang diteliti adalah pemberian aquadem sebagai kontrol, pemberian kapsul daun sendok sebagai bahan uji dan pemberian obat antalgin sebagai bahan pembanding. Variabel tergantung dari penelitian ini adalah gradasi eritema dan persentase perubahan luas area eritema. Hewan coba yang digunakan dalam penelitian ini adalah marmut putih betina (guinea pig) sebanyak 30 ekor dengan berat 300-400 g. Marmut dalam keadaan sehat, tanpa cacat maupun luka.

\section{SKEMA PENGUJIAN}

Hewan uji yang digunakan adalah marmut putih betina (guinea pig) strain Hartley albino. Jumlah hewan uji sebanyak 30 ekor dengan berat berkisar 300-400gram dibagi menjadi 3 kelompok secara acak (random). Hewan uji yang telah dibagi ditimbang beratnya per kelompok dan diletakkan di kandang yang bersih untuk diadaptasikan selama 1-2 minggu.

Bagian punggung hewan uji dicukur dengan alat pencukur elektrik dan diberi obat penghilang bulu untuk membersihkan sisa-sisa bulu. Bagian punggung yang telah dicukur diberi tanda pengamatan berupa persegi dengan luas $30 \mathrm{~cm}^{2}$. Sebelum hewan uji diradiasi, lampu UV dihidupkan terlebih dahulu selama 30 menit.

Hewan uji diberi bahan sesuai kelompoknya yaitu kelompok kontrol diberi aquadem sebanyak $4 \mathrm{ml}$ tiap 5 jam sekali sehari (4 kali sehari), kelompok pembanding diberi obat antalgin dengan dosis $50 \mathrm{mg} / \mathrm{kg}$ sebanyak $4 \mathrm{ml}$ tiap 5 jam sekali sehari (4 kali sehari), dimana dosis larutan antalgin adalah $250 \mathrm{mg} / \mathrm{ml}$ diencerkan menjadi $5 \mathrm{mg} / \mathrm{ml}$ dengan cara mengambil $1 \mathrm{ml}$ larutan antalgin dan ditambahkan add $50 \mathrm{ml}$ aquadem dalam labu ukur dan kelompok uji diberi kapsul daun sendok dengan dosis $50 \mathrm{mg} / \mathrm{kg}$ sebanyak $4 \mathrm{ml}$ tiap 5 jam sekali sehari (4 kali sehari), dimana dosis daun sendok diperoleh dari penyeduhan serbuk daun sendok dengan dosis $50 \mathrm{mg} / \mathrm{kg}$.

Hewan uji didiamkan selama 30 menit lalu diinduksi dengan sinar UV-B (290-320 nm) selama 30 menit dengan jarak ketinggian sinar radiasi adalah $10 \mathrm{~cm}$. Pengamatan terhadap eritema yang muncul menggunakan loop dan dilakukan setiap kali pemberian bahan uji, pembanding dan kontrol. Parameter yang digunakan adalah gradasi eritema dan persentase perubahan luas area eritema.

\section{ANALISIS PENELITIAN}

Data yang digunakan adalah luas area eritema dan gradasi eritema. Metode pengukuran luas area eritema dengan melihat persentase perubahan luas area eritema dan perbandingan luas area eritema setiap kelompok. Perhitungan data luas area eritema setiap kelompok perlakuan menggunakan uji t-berpasangan, sedangkan perhitungan persentase perubahan luas area eritema menggunakan uji ANAVA.

Metode pengukuran berupa gradasi warna eritema adalah pengamatan pada bagian warna kulit yang dimasukkan dalam bentuk skor dengan rentang 0-4 adalah (Okumura, 2004):

- Skor $0=$ tidak terjadi apapun (warna kulit tidak terjadi kemerahan)

- Skor 1 = warna kulit mulai kemerahan yang tidak jelas (eritema sedikit)

- Skor 2 = warna kulit kemerahan dan tidak ada bintik merah yang terlihat (eritema berbatas jelas)

- Skor 3 = warna kulit merah (eritema sedang)

- Skor 4 = warna kulit merah sekali (eritema banyak)

Hasil data skor dalam 24 jam dihitung dengan

uji Kruskal-Wallis (non-parametrik) yang dilengkapi dengan nilai Seri, bila ada perbedaan bermakna pada perlakuan dan dilanjutkan dengan uji Pembandingan Berganda. Untuk gradasi warna eritema setelah diradiasi sinar UV-B dengan 24 jam setelah diradiasi sinar UV-B dianalisa dengan menggunakan uji Man-Whitney untuk masingmasing kelompok perlakuan.

HASIL PENELITIAN DAN PEMBAHASAN

1. Gradasi Eritema

a. Skor Gradasi Eritema pada masing-masing Kelompok Kontrol, Uji dan Pembanding. 
EFEK EKSTRAK DAUN SENDOK (Plantago major L.) TERHADAP ERITEMA PADA MARMUT PUTIH BETINA (Guinea pig) OLEH RADIASI ALAT MODIFIKASI UV 04-08

Data yang diperoleh berupa skor gradasi eritema sebelum diradiasi, setelah diradiasi sinar UV-B dan 24 jam setelah diradiasi sinar UV-B tiap masing-masing kelompok perlakuan, hasilnya dapat dilihat pada tabel masing-masing kelompok berikut ini:

Tabel 1. Skor Gradasi Eritema Kelompok Kontrol, Uji dan Pembanding Dilihat Sebelum Diradiasi Sinar UV-B, Setelah Diradiasi Sinar UV-B dan 24 jam Setelah Diradiasi Sinar UV-B Selama 30 menit.

\begin{tabular}{|c|c|c|c|c|c|}
\hline Kelompok & Perlakuan & $\begin{array}{c}\text { No } \\
\text { Marmut }\end{array}$ & $\begin{array}{c}\text { Gradasi Eritema } \\
\text { Sebelum } \\
\text { Diradiasi } \\
\text { Sinar UV-B }\end{array}$ & $\begin{array}{c}\text { Gradasi Eritema } \\
\text { Setelah } \\
\text { Diradiasi } \\
\text { Sinar UV-B }\end{array}$ & $\begin{array}{c}\text { Gradasi Eritema } \\
24 \text { jam setelah } \\
\text { Diradiasi } \\
\text { Sinar UV-B }\end{array}$ \\
\hline \multirow[t]{10}{*}{ Kontrol } & Diberi aquadem & 1 & 0 & 4 & 3 \\
\hline & secara oral & 2 & 0 & 4 & 4 \\
\hline & setiap 5 jam & 3 & 0 & 4 & 4 \\
\hline & dan diradiasi & 4 & 0 & 4 & 4 \\
\hline & sinar UV-B & 5 & 0 & 4 & 3 \\
\hline & selama 30 menit & 6 & 0 & 4 & 4 \\
\hline & & 7 & 0 & 4 & 4 \\
\hline & & 8 & 0 & 4 & 4 \\
\hline & & 9 & 0 & 4 & 3 \\
\hline & & 10 & 0 & 4 & 3 \\
\hline \multicolumn{3}{|c|}{ Jumlah } & 0 & 40 & 36 \\
\hline \multicolumn{3}{|c|}{ Rata-rata (dibulatkan) } & 0 & 4 & 4 \\
\hline \multicolumn{3}{|c|}{$\mathrm{SD}$} & & 0 & 0,52 \\
\hline \multirow[t]{10}{*}{ Uji } & Diberi ekstrak & 1 & 0 & 4 & 2 \\
\hline & daun sendok & 2 & 0 & 4 & 1 \\
\hline & $50 \mathrm{mg} / \mathrm{kg}$ & 3 & 0 & 4 & 2 \\
\hline & secara oral & 4 & 0 & 4 & 2 \\
\hline & setiap 5 jam & 5 & 0 & 4 & 2 \\
\hline & dan diradiasi & 6 & 0 & 4 & 2 \\
\hline & sinar UV-B & 7 & 0 & 4 & 1 \\
\hline & selama 30 menit & 8 & 0 & 4 & 2 \\
\hline & & 9 & 0 & 4 & 2 \\
\hline & & 10 & 0 & 4 & 2 \\
\hline \multicolumn{3}{|c|}{ Jumlah } & 0 & 40 & 18 \\
\hline \multicolumn{3}{|c|}{ Rata-rata (dibulatkan) } & 0 & 4 & 2 \\
\hline \multicolumn{3}{|c|}{$\mathrm{SD}$} & & 0 & 0,42 \\
\hline \multirow[t]{10}{*}{ Pembanding } & Diberi larutan & 1 & 0 & 4 & 1 \\
\hline & antalgin & 2 & 0 & 4 & 1 \\
\hline & $50 \mathrm{mg} / \mathrm{kg}$ & 3 & 0 & 4 & 1 \\
\hline & secara oral & 4 & 0 & 4 & 0 \\
\hline & setiap 5 jam & 5 & 0 & 4 & 1 \\
\hline & dan diradiasi & 6 & 0 & 4 & 0 \\
\hline & sinar UV-B & 7 & 0 & 4 & 1 \\
\hline & selama 30 menit & 8 & 0 & 4 & 1 \\
\hline & & 9 & 0 & 4 & 1 \\
\hline & & 10 & 0 & 4 & 0 \\
\hline \multicolumn{3}{|c|}{ Jumlah } & 0 & 40 & 7 \\
\hline \multicolumn{3}{|c|}{ Rata-rata (dibulatkan) } & 0 & 4 & 1 \\
\hline \multicolumn{3}{|c|}{$\mathrm{SD}$} & & 0 & 0,48 \\
\hline
\end{tabular}

Data pada tabel 1 dilakukan analisa statistik dengan menggunakan Uji MannWhitney pada masing-masing kelompok antara setelah diradiasi Sinar UV-B dengan 24 jam setelah diradiasi sinar UV-B. Hasil analisa pada kelompok kontrol tidak memiliki efek anti- 
inflamasi. Hasil analisa kelompok uji memiliki efek anti-inflamasi dan hasil analisa kelompok pembanding memiliki efek anti-inflamasi.

b. Skor Gradasi Eritema Kelompok Kontrol, Uji dan Pembanding pada 24 jam Setelah Diradiasi Sinar UV-B
Data yang diperoleh berupa skor gradasi eritema pada 24 jam setelah diradiasi sinar UV$\mathrm{B}$, hasilnya dapat dilihat pada tabel 2 berikut ini:

Tabel 2. Skor Gradasi Eritema Kelompok Kontrol, Uji dan Pembanding Dilihat 24 jam Setelah Diradiasi Sinar UV-B Selama 30 menit.

\begin{tabular}{|c|c|c|c|c|c|}
\hline Kelompok & Perlakuan & $\begin{array}{c}\text { No } \\
\text { Marmut }\end{array}$ & $\begin{array}{c}\text { Gradasi Eritema } \\
\text { Sebelum } \\
\text { Diradiasi } \\
\text { Sinar UV-B }\end{array}$ & $\begin{array}{c}\text { Gradasi Eritema } \\
\text { Setelah } \\
\text { Diradiasi } \\
\text { Sinar UV-B }\end{array}$ & $\begin{array}{c}\text { Gradasi Eritema } \\
24 \text { jam setelah } \\
\text { Diradiasi } \\
\text { Sinar UV-B }\end{array}$ \\
\hline \multirow[t]{10}{*}{ Kontrol } & \multirow{10}{*}{$\begin{array}{l}\text { Diberi aquadem } \\
\text { secara oral } \\
\text { setiap } 5 \text { jam } \\
\text { dan diradiasi } \\
\text { sinar UV-B } \\
\text { selama } 30 \text { menit }\end{array}$} & 1 & 0 & 4 & 3 \\
\hline & & 2 & 0 & 4 & 4 \\
\hline & & 3 & 0 & 4 & 4 \\
\hline & & 4 & 0 & 4 & 4 \\
\hline & & 5 & 0 & 4 & 3 \\
\hline & & 6 & 0 & 4 & 4 \\
\hline & & 7 & 0 & 4 & 4 \\
\hline & & 8 & 0 & 4 & 4 \\
\hline & & 9 & 0 & 4 & 3 \\
\hline & & 10 & 0 & 4 & 3 \\
\hline \multicolumn{3}{|c|}{ Jumlah } & 0 & 40 & 36 \\
\hline \multicolumn{3}{|c|}{ Rata-rata (dibulatkan) } & 0 & 4 & 4 \\
\hline \multicolumn{3}{|c|}{ SD } & & 0 & 0,52 \\
\hline \multirow[t]{10}{*}{ Uji } & \multirow{10}{*}{$\begin{array}{c}\text { Diberi ekstrak } \\
\text { daun sendok } \\
50 \mathrm{mg} / \mathrm{kg} \\
\text { secara oral } \\
\text { setiap } 5 \text { jam } \\
\text { dan diradiasi } \\
\text { sinar UV-B } \\
\text { selama } 30 \text { menit }\end{array}$} & 1 & 0 & 4 & 2 \\
\hline & & 2 & 0 & 4 & 1 \\
\hline & & 3 & 0 & 4 & 2 \\
\hline & & 4 & 0 & 4 & 2 \\
\hline & & 5 & 0 & 4 & 2 \\
\hline & & 6 & 0 & 4 & 2 \\
\hline & & 7 & 0 & 4 & 1 \\
\hline & & 8 & 0 & 4 & 2 \\
\hline & & 9 & 0 & 4 & 2 \\
\hline & & 10 & 0 & 4 & 2 \\
\hline \multicolumn{3}{|c|}{ Jumlah } & 0 & 40 & 18 \\
\hline \multicolumn{3}{|c|}{ Rata-rata (dibulatkan) } & 0 & 4 & $2 \mathrm{~b}$ \\
\hline \multicolumn{3}{|c|}{ SD } & & 0 & 0,42 \\
\hline \multirow[t]{10}{*}{ Pembanding } & \multirow{10}{*}{$\begin{array}{c}\text { Diberi larutan } \\
\text { antalgin } \\
50 \mathrm{mg} / \mathrm{kg} \\
\text { secara oral } \\
\text { setiap } 5 \text { jam } \\
\text { dan diradiasi } \\
\text { sinar UV-B } \\
\text { selama } 30 \text { menit }\end{array}$} & 1 & 0 & 4 & 1 \\
\hline & & 2 & 0 & 4 & 1 \\
\hline & & 3 & 0 & 4 & 1 \\
\hline & & 4 & 0 & 4 & 0 \\
\hline & & 5 & 0 & 4 & 1 \\
\hline & & 6 & 0 & 4 & 0 \\
\hline & & 7 & 0 & 4 & 1 \\
\hline & & 8 & 0 & 4 & 1 \\
\hline & & 9 & 0 & 4 & 1 \\
\hline & & 10 & 0 & 4 & 0 \\
\hline \multicolumn{3}{|c|}{ Jumlah } & 0 & 40 & 7 \\
\hline \multicolumn{3}{|c|}{ Rata-rata (dibulatkan) } & 0 & 4 & $1 \mathrm{a}$ \\
\hline \multicolumn{3}{|c|}{ SD } & & 0 & 0,48 \\
\hline
\end{tabular}

Keterangan: Angka-angka yang diikuti oleh huruf berbeda berarti ada perbedaan bermakna dengan uji Pembandingan Berganda pada $\alpha=0,05$. 
Data pada tabel 2 juga dianalisa secara statistika dengan menggunakan uji KruskalWallis (uji non-parametrik) yang diikuti dengan pengukuran nilai seri.
Untuk melengkapi data dalam tabel 2, dapat dilihat pada histogram rata-rata skor gradasi eritema pada masing-masing kelompok di bawah ini:

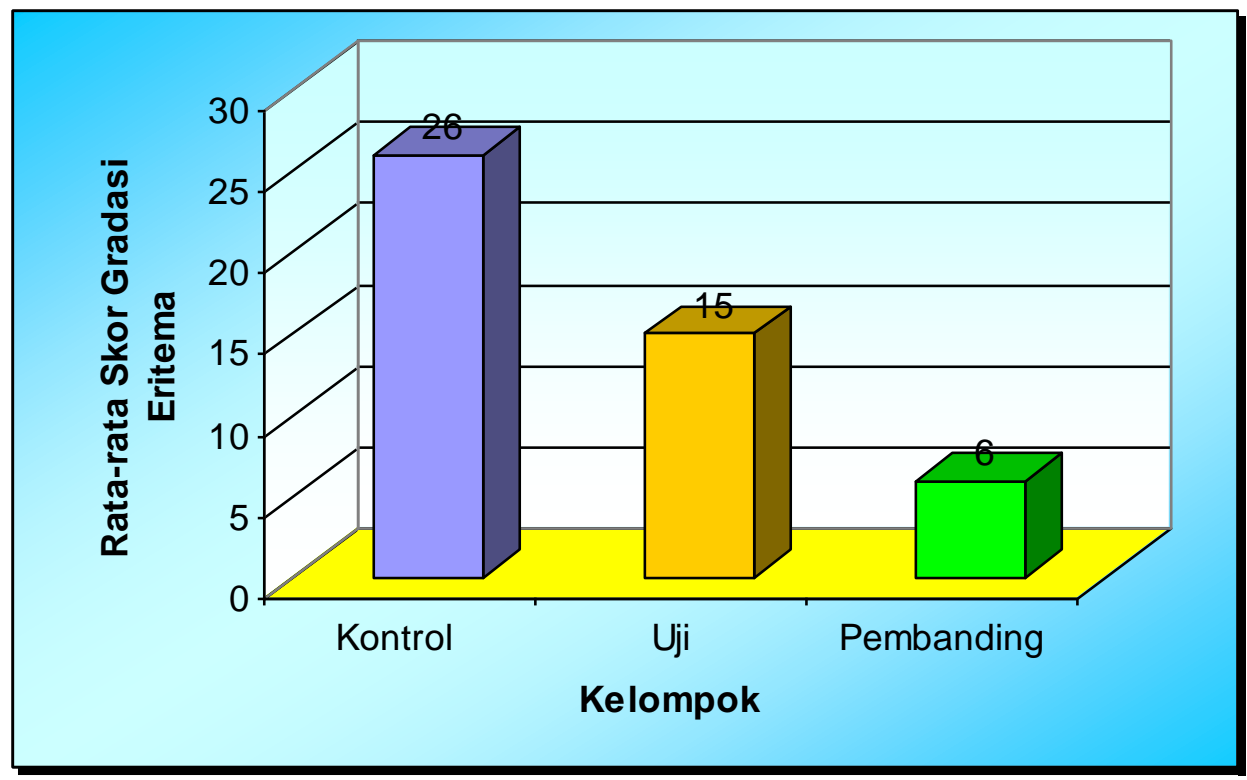

Gambar 1. Histogram Rata-Rata Skor Gradasi Eritema Kelompok Kontrol, Uji dan Pembanding pada 24 jam Setelah Diradiasi Sinar UV-B (290-320 nm) Selama 30 menit

Berdasarkan hasil analisa rata-rata skor gradasi eritema pada 24 jam setelah diradiasi sinar UV-B didapatkan bahwa ada perbedaan yang signifikan gradasi eritema antara kelompok kontrol, uji dan pembanding. Untuk mengetahui kelompok yang mana memberikan perbedaan bermakna pada gradasi eritema, maka dilanjutkan dengan uji Pembandingan Berganda.

Hasil yang didapatkan berupa kelompok kontrol dengan kelompok uji diikuti oleh huruf berbeda artinya ada perbedaan gradasi eritema antara kelompok kontrol dan uji pada 24 jam setelah diradiasi sinar UV-B, sedangkan untuk kelompok pembanding dengan kelompok uji diikuti oleh huruf yang berbeda artinya ada perbedaan gradasi eritema antara kelompok pembanding dengan kelompok uji pada 24 jam setelah diradiasi sinar UV-B.

\section{c. Persentase Penurunan Skor Gradasi Eritema Kelompok Kontrol, Uji dan Pembanding. \\ Data yang diperoleh berupa persentase} penurunan skor gradasi eritema setelah diradiasi sinar UV-B dengan 24 jam setelah diradiasi sinar UV-B. Untuk melengkapi data dalam tabel 2, dapat dilihat pada histogram persentase penurunan skor gradasi eritema pada masing-masing kelompok di bawah ini: 


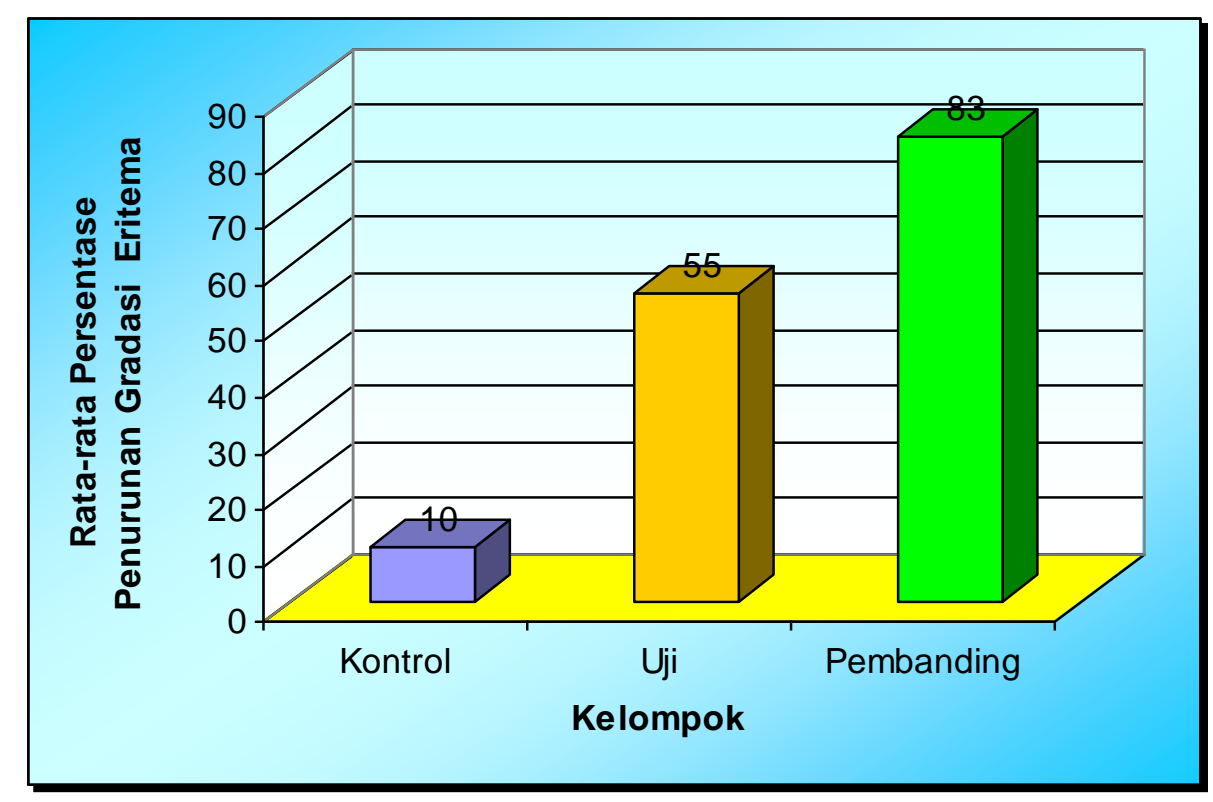

Gambar 3. Histogram Rata-Rata Persentase Penurunan Skor Gradasi Eritema Kelompok Kontrol, Uji dan Pembanding Setelah Diradiasi Sinar UV-B dengan 24 jam Setelah Diradiasi Sinar UV-B (290-320 nm) Selama 30 menit.

Berdasarkan hasil rata-rata persentase penurunan skor gradasi eritema antara setelah diradiasi sinar UV-B dan 24 jam setelah diradiasi sinar UV-B didapatkan bahwa ada perbedaan yang signifikan antara kelompok kontrol, uji dan pembanding. Dilihat dari ratarata persentase penurunan skor gradasi eritema pada kelompok kontrol sebesar $10 \%$, pada kelompok uji sebesar 55\% dan kelompok pembanding sebesar $83 \%$. Perbandingan kekuatan dalam menurunkan gradasi eritema pada kelompok uji adalah 4,5 kali dari pada kelompok kontrol, sedangkan perbandingan kekuatan dalam menurunkan gradasi eritema pada kelompok pembanding adalah 0,5 kali daripada kelompok uji. Jadi dapat disimpulkan bahwa kelompok uji memiliki efek anti- inflamasi dalam menurunkan gradasi eritema dibandingkan kelompok kontrol dan efek antiinflamasi kelompok uji dalam menurunkan gradasi eritema tidak sebaik kelompok pembanding.

\section{Luas Area Eritema}

a. Luas Area Eritema pada masing-masing Kelompok Kontrol, Uji dan Pembanding. Data yang diperoleh berupa luas area eritema tiap masing-masing kelompok perlakuan, hasilnya dapat dilihat pada tabel 3 pada masing-masing kelompok berikut ini:

Tabel 3. Luas Area Eritema Kelompok Kontrol, Uji dan Pembanding Dilihat Setelah Diradiasi Sinar UV-B dan 24 jam Setelah Diradiasi Sinar UV-B Selama 30 menit.

\begin{tabular}{|c|c|c|c|c|}
\hline \multirow[b]{2}{*}{ Kelompok } & \multirow[b]{2}{*}{ Perlakuan } & \multirow[b]{2}{*}{ No Marmut } & \multicolumn{2}{|c|}{ Luas Area Eritema } \\
\hline & & & $\begin{array}{c}\text { Setelah } \\
\text { Diradiasi } \\
\text { Sinar UV-B } \\
\left(\mathbf{c m}^{2}\right)\end{array}$ & $\begin{array}{c}24 \text { jam Setelah } \\
\text { Diradiasi } \\
\text { Sinar UV-B } \\
\left(\mathrm{cm}^{2}\right)\end{array}$ \\
\hline \multirow{6}{*}{ Kontrol } & \multirow{6}{*}{$\begin{array}{l}\text { Diberi aquadem } \\
\text { secara oral } \\
\text { setiap } 5 \text { jam } \\
\text { dan diradiasi } \\
\text { sinar UV-B } \\
\text { selama } 30 \text { menit }\end{array}$} & 1 & 26 & 18 \\
\hline & & 2 & 26,7 & 26,7 \\
\hline & & 3 & 26,6 & 26,6 \\
\hline & & 4 & 24 & 24 \\
\hline & & 5 & 27,4 & 26,8 \\
\hline & & 6 & 25,9 & 25,9 \\
\hline
\end{tabular}


EFEK EKSTRAK DAUN SENDOK (Plantago major L.) TERHADAP ERITEMA PADA MARMUT PUTIH BETINA (Guinea pig) OLEH RADIASI ALAT MODIFIKASI UV 04-08

\begin{tabular}{|c|c|c|c|c|}
\hline \multirow[b]{2}{*}{ Kelompok } & \multirow[b]{2}{*}{ Perlakuan } & \multirow[b]{2}{*}{ No Marmut } & \multicolumn{2}{|c|}{ Luas Area Eritema } \\
\hline & & & $\begin{array}{c}\text { Setelah } \\
\text { Diradiasi } \\
\text { Sinar UV-B } \\
\left(\mathrm{cm}^{2}\right)\end{array}$ & $\begin{array}{c}24 \text { jam Setelah } \\
\text { Diradiasi } \\
\text { Sinar UV-B } \\
\left(\mathrm{cm}^{2}\right)\end{array}$ \\
\hline & & 7 & 26 & 26 \\
\hline & & 8 & 24,2 & 24,2 \\
\hline & & 9 & 26,3 & 25,4 \\
\hline & & 10 & 25,3 & 24,9 \\
\hline \multicolumn{3}{|c|}{ Jumlah } & 258,3 & 248,4 \\
\hline \multicolumn{3}{|c|}{ Rata-rata } & 25,8 & 24,8 \\
\hline \multicolumn{3}{|c|}{ SD } & 1,07 & 2,59 \\
\hline \multirow[t]{10}{*}{ Uji } & \multirow{10}{*}{$\begin{array}{l}\text { Diberi ekstrak } \\
\text { daun sendok } \\
50 \mathrm{mg} / \mathrm{kg} \\
\text { secara oral } \\
\text { setiap } 5 \text { jam } \\
\text { dan diradiasi } \\
\text { sinar UV-B } \\
\text { selama } 30 \text { menit }\end{array}$} & 1 & 21 & 10 \\
\hline & & 2 & 20,5 & 8,5 \\
\hline & & 3 & 25 & 12 \\
\hline & & 4 & 20 & 10 \\
\hline & & 5 & 24,2 & 10 \\
\hline & & 6 & 22,1 & 12,5 \\
\hline & & 7 & 25,5 & 8 \\
\hline & & 8 & 20 & 11 \\
\hline & & 9 & 23,2 & 15 \\
\hline & & 10 & 24 & 11,5 \\
\hline \multicolumn{3}{|c|}{ Jumlah } & 225,5 & 108,5 \\
\hline \multicolumn{3}{|c|}{ Rata-rata } & 22,6 & 10,9 \\
\hline \multicolumn{3}{|c|}{ SD } & 2,1 & 2,04 \\
\hline \multirow[t]{10}{*}{ Pembanding } & \multirow{10}{*}{$\begin{array}{c}\text { Diberi larutan } \\
\text { antalgin } \\
50 \mathrm{mg} / \mathrm{kg} \\
\text { secara oral } \\
\text { setiap } 5 \text { jam } \\
\text { dan diradiasi } \\
\text { sinar UV-B } \\
\text { selama } 30 \text { menit }\end{array}$} & 1 & 21,5 & 0,75 \\
\hline & & 2 & 22,6 & 0,60 \\
\hline & & 3 & 20 & 0,84 \\
\hline & & 4 & 20,5 & 0 \\
\hline & & 5 & 20,7 & 0,82 \\
\hline & & 6 & 20 & 0 \\
\hline & & 7 & 23,2 & 0,47 \\
\hline & & 8 & 22,5 & 0,95 \\
\hline & & 9 & 24 & 0,42 \\
\hline & & 10 & 21,6 & 0 \\
\hline \multicolumn{3}{|c|}{ Jumlah } & 216,6 & 4,9 \\
\hline \multicolumn{3}{|c|}{ Rata-rata } & 21,7 & 0,5 \\
\hline \multicolumn{3}{|c|}{ SD } & 1,4 & 0,4 \\
\hline
\end{tabular}

Keterangan: Data luas area eritema sesaat setelah diinduksi dengan data luas area eritema 24 jam setelah diinduksi sinar UV-B dianalisis dengan uji t-berpasangan dan ada perbedaan bermakna pada $\alpha$ $=0,05$

Data pada tabel 3 dianalisa statistik dengan menggunakan Uji t-berpasangan. Hasil analisa pada kelompok kontrol dilihat dari luas area eritema setelah diradiasi sinar UV-B tidak terdapat perbedaan yang signifikan dengan luas area eritema setelah 24 jam diradiasi sinar UVB. Jadi kelompok kontrol tidak memiliki efek anti-inflamasi. Untuk hasil analisa pada kelompok uji dilihat dari luas area eritema setelah diradiasi sinar UV-B terdapat perbedaan yang signifikan dengan luas area eritema setelah 24 jam diradiasi sinar UV-B. Jadi kelompok uji memiliki efek anti-inflamasi. Sedangkan hasil analisa pada kelompok pembanding dilihat dari luas area eritema setelah diradiasi sinar UV-B terdapat perbedaan yang signifikan dengan luas area eritema setelah 24 jam diradiasi sinar UV-B. Jadi kelompok pembanding memiliki efek antiinflamasi.

b. Persentase Perubahan Luas Area Eritema pada Kelompok Kontrol, Uji dan Pembanding.

Data yang diperoleh berupa persentase perubahan luas area eritema, hasilnya dapat dilihat pada tabel 4 berikut ini: 
Tabel 4. Persentase Perubahan Luas Area Eritema Pada Kelompok Kontrol, Uji dan Pembanding Setelah Diradiasi Sinar UV-B dan 24 jam Setelah Diradiasi Sinar UV-B Selama 30 menit

\begin{tabular}{|c|c|c|c|c|c|}
\hline \multirow[t]{2}{*}{ Kelompok } & \multirow[t]{2}{*}{ Perlakuan } & \multirow{2}{*}{$\begin{array}{c}\text { No } \\
\text { Marmut }\end{array}$} & \multicolumn{2}{|c|}{ Luas Area Eritema } & \multirow[b]{2}{*}{$\begin{array}{c}\% \\
\text { Persentase } \\
\text { Perubahan } \\
\text { Luas Area } \\
\text { Eritema }\end{array}$} \\
\hline & & & $\begin{array}{c}\text { Setelah } \\
\text { Diradiasi } \\
\text { Sinar UV-B } \\
\left(\mathbf{c m}^{2}\right) \\
\end{array}$ & $\begin{array}{c}24 \text { jam Setelah } \\
\text { Diradiasi } \\
\text { Sinar UV-B } \\
\left(\mathrm{cm}^{2}\right)\end{array}$ & \\
\hline \multirow[t]{10}{*}{ Kontrol } & \multirow{10}{*}{$\begin{array}{l}\text { Diberi aquadem } \\
\text { secara oral } \\
\text { setiap } 5 \text { jam } \\
\text { dan diradiasi } \\
\text { sinar UV-B } \\
\text { selama } 30 \text { menit }\end{array}$} & 1 & 26 & 18 & 30,8 \\
\hline & & 2 & 26,7 & 26,7 & 0 \\
\hline & & 3 & 26,6 & 26,6 & 0 \\
\hline & & 4 & 24 & 24 & 0 \\
\hline & & 5 & 27,4 & 26,8 & 2,2 \\
\hline & & 6 & 25,9 & 25,9 & 0 \\
\hline & & 7 & 26 & 26 & 0 \\
\hline & & 8 & 24,2 & 24,2 & 0 \\
\hline & & 9 & 26,3 & 25,4 & 3,4 \\
\hline & & 10 & 25,3 & 24,9 & 1,6 \\
\hline \multicolumn{3}{|c|}{ Jumlah } & 258,3 & 248,4 & 37,7 \\
\hline \multicolumn{3}{|c|}{ Rata-rata } & 25,8 & 24,8 & $3,8 \mathrm{a}$ \\
\hline \multicolumn{3}{|c|}{ SD } & 1,07 & 2,59 & 9,6 \\
\hline \multirow[t]{10}{*}{ Uji } & \multirow{10}{*}{$\begin{array}{c}\text { Diberi ekstrak } \\
\text { daun sendok } \\
50 \mathrm{mg} / \mathrm{kg} \\
\text { secara oral } \\
\text { setiap } 5 \mathrm{jam} \\
\text { dan diradiasi } \\
\text { sinar UV-B } \\
\text { selama } 30 \text { menit }\end{array}$} & 1 & 21 & 10 & 52,4 \\
\hline & & 2 & 20,5 & 8,5 & 58,5 \\
\hline & & 3 & 25 & 12 & 52 \\
\hline & & 4 & 20 & 10 & 50 \\
\hline & & 5 & 24,2 & 10 & 58,7 \\
\hline & & 6 & 22,1 & 12,5 & 43,4 \\
\hline & & 7 & 25,5 & 8 & 68,6 \\
\hline & & 8 & 20 & 11 & 45 \\
\hline & & 9 & 23,2 & 15 & 35,3 \\
\hline & & 10 & 24 & 11,5 & 58,1 \\
\hline \multicolumn{3}{|c|}{ Jumlah } & 225,5 & 108,5 & 522 \\
\hline \multicolumn{3}{|c|}{ Rata-rata } & 22,6 & 10,9 & $52,2 \mathrm{~b}$ \\
\hline \multicolumn{3}{|c|}{ SD } & 2,1 & 2,04 & 9,5 \\
\hline \multirow[t]{10}{*}{ Pembanding } & \multirow{10}{*}{$\begin{array}{c}\text { Diberi larutan } \\
\text { antalgin } \\
50 \mathrm{mg} / \mathrm{kg} \\
\text { secara oral } \\
\text { setiap } 5 \text { jam } \\
\text { dan diradiasi } \\
\text { sinar UV-B } \\
\text { selama } 30 \text { menit }\end{array}$} & 1 & 21,5 & 0,75 & 96,5 \\
\hline & & 2 & 22,6 & 0,60 & 97,5 \\
\hline & & 3 & 20 & 0,84 & 95,8 \\
\hline & & 4 & 20,5 & 0 & 100 \\
\hline & & 5 & 20,7 & 0,82 & 96,04 \\
\hline & & 6 & 20 & 0 & 100 \\
\hline & & 7 & 23,2 & 0,47 & 97,9 \\
\hline & & 8 & 22,5 & 0,95 & 95,8 \\
\hline & & 9 & 24 & 0,42 & 98,3 \\
\hline & & 10 & 21,6 & 0 & 100 \\
\hline \multicolumn{3}{|c|}{ Jumlah } & 216,6 & 4,9 & 977,8 \\
\hline \multicolumn{3}{|c|}{ Rata-rata } & 21,7 & 0,5 & $97,8 \mathrm{c}$ \\
\hline \multicolumn{3}{|c|}{ SD } & 1,4 & 0,4 & 1,8 \\
\hline
\end{tabular}

Keterangan: Angka-angka yang diikuti oleh huruf berbeda berarti ada perbedaan bermakna dengan uji BNT pada $\alpha=0,05$

Data pada tabel 4 dianalisa secara statistika dengan menggunakan uji ANAVA pada derajat kemaknaan $\alpha=5 \%$. Untuk melengkapi data dalam tabel 4 dapat dilihat histogram rata-rata persentase perubahan luas area eritema pada kelompok kontrol, uji dan pembanding di bawah ini: 


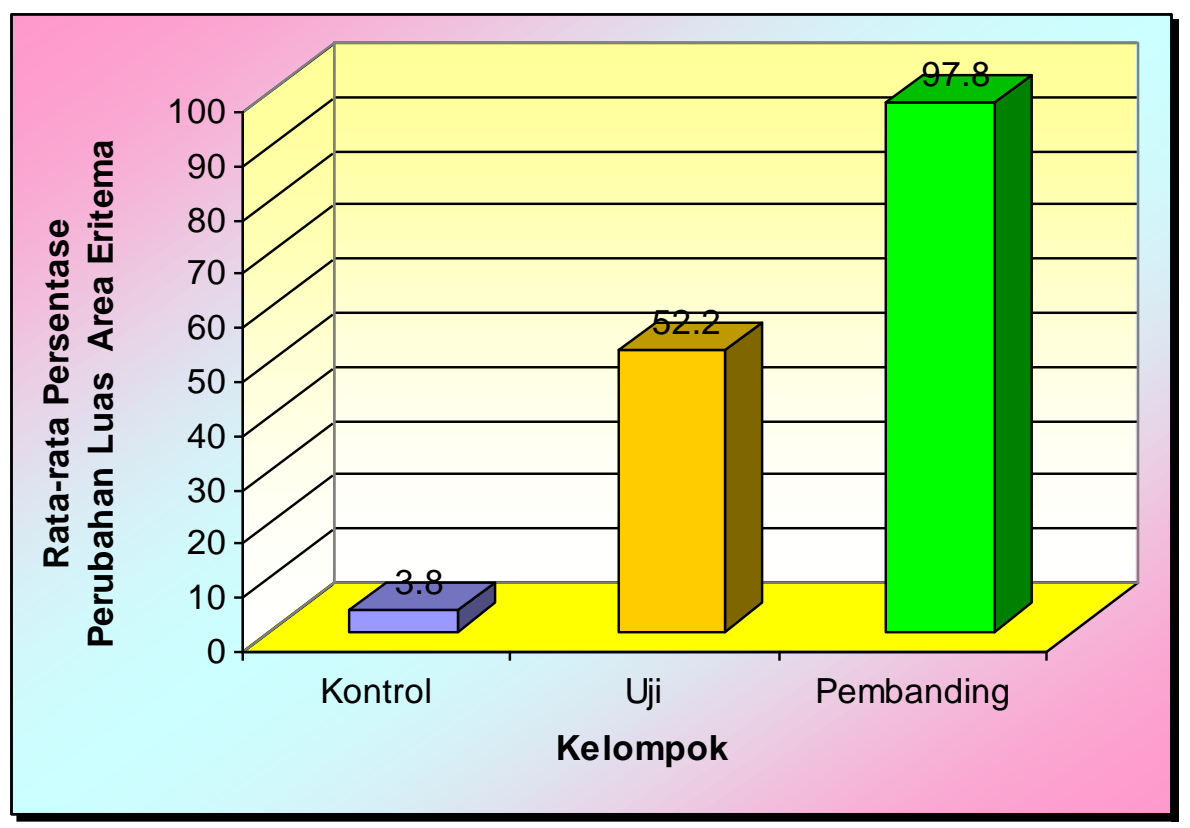

\section{Gambar 26. Histogram Rata-Rata Persentase Perubahan Luas Eritema Pada Kelompok Kontrol, Uji dan Pembanding.}

Berdasarkan hasil rata-rata persentase perubahan luas area eritema setelah diradiasi sinar UV-B dan 24 jam setelah diradiasi sinar UV-B didapatkan bahwa terdapat perbedaan yang signifikan antara kelompok kontrol, uji dan pembanding. Untuk mengetahui kelompok yang mana memberikan perbedaan yang signifikan, maka dilanjutkan dengan uji BNT dengan $\alpha=5 \%$.

Hasil yang didapatkan bahwa kelompok uji dan pembanding diikuti oleh huruf yang berbeda dengan kelompok kontrol yang artinya kelompok uji dan pembanding memiliki persentase perubahan luas area eritema yang berbeda signifikan dibandingkan dengan kelompok kontrol. Untuk hasil pada kelompok uji yang dibandingkan dengan kelompok pembanding diikuti huruf yang berbeda, artinya kelompok uji memiliki persentase perubahan luas area eritema yang berbeda signifikan yang dibandingkan dengan persentase perubahan luas area eritema pada kelompok pembanding. Jadi berdasarkan persentase perubahan luas area eritema kelompok uji memiliki efek antiinflamasi, tetapi efek anti-inflamasinya tidak sebaik antalgin.

Dalam penelitian ini dilakukan pengujian terhadap efek anti-inflamasi daun sendok (Plantago major L) yang diberikan secara oral dalam bentuk ekstrak cair, karena air merupakan pelarut polar yang dapat menarik semua kandungan yang bersifat polar salah satunya kandungan yang berfungsi sebagai antiinflamasi. Untuk bahan pembanding digunakan antalgin yang termasuk obat antiinflamasi golongan NSAID karena antalgin merupakan obat yang memiliki sifat analgesik, antipiretik dan anti-inflamasi yang seimbang sehingga digunakan sebagai standard dalam penelitian ini.

Berdasarkan hasil analisa pada gradasi eritema dan luas area eritema, kelompok kontrol yang diberi aquadem tidak memiliki efek anti-inflamasi, kelompok uji yang diberi ekstrak daun sendok (yang diperoleh dari penyeduhan serbuk daun sendok dengan dosis $50 \mathrm{mg} / \mathrm{kg}$ ) memiliki efek anti-inflamasi dan kelompok pembanding yang diberi larutan antalgin dengan dosis $50 \mathrm{mg} / \mathrm{kg}$ memiliki efek anti-inflamasi. Akan tetapi efek anti-inflamasi ekstrak daun sendok tidak sebaik efek antiinflamasi pada antalgin.

Ini disebabkan oleh antalgin merupakan obat yang mekanisme kerjanya menghambat jalur siklooksigenase. Eritema yang disebabkan oleh sinar UV-B menyebabkan vasodilatasi, peningkatan permeabilitas vaskuler dan memicu pengeluaran mediator-mediator peradangan yaitu histamin, prostaglandin dan leukotrien, dengan penggunaan antalgin yang memiliki efek anti-inflamasi maka dapat menghambat jalur siklooksigenase sehingga produksi prostaglandin dihambat dan histamin juga dihambat karena prostaglandin merupakan vasodilator kuat yang memicu kepekaan reseptor peradangan yaitu histamin. 
Untuk ekstrak daun sendok masih merupakan simplisia yang kandungan antiinflamasinya belum mengalami isolasi, skrining atau proses yang lebih spesifik terhadap kandungan anti-inflamasi. Kandungan ekstrak daun sendok yang diduga memiliki khasiat anti-inflamasi adalah asam klorogenat, asam salisilat, aukubin, baicalein, $\beta$-sitosterol, catalpol, asam askorbat dan tannin.

Mekanisme kerja kandungan ekstrak daun sendok adalah asam salisilat dapat menghambat atau memblok sintesis prostaglandin yang mana telah dibuktikan dalam penelitian terhadap tanaman Salix Alba, asam klorogenat berdasarkan Calixto J.B et.al bahwa dapat menghambat produksi IL-1 $\beta$, TNF $\alpha$, IL-6, aukubin berdasarkan Calixto J.B et.al bahwa dapat menghambat produksi TNF $\alpha$ dan IL-6, baicalein dapat menghambat produksi dan ekspresi IL-6 dan IL-8 yang mana telah dibuktikan dalam penelitian terhadap tanaman Scutellaria baicalensis Georgi (lamiaceae), ßsitosterol dapat menurunkan atau menghambat pelepasan IL-2 dari sel dan mengeluarkan reaksi imun tubuh yang mana telah dibuktikan dalam penelitian Human Jurkat T Cells, catapol dapat mencegah produksi TNF $\alpha$, IL- $1 \beta$ dan IL6 yang mana telah dibuktikan dalam penelitian tanaman Catalpa ovata G.Don (Bignoniaceae), tanin dan asam askorbat dapat menurunkan permeabilitas vaskuler dan mekanisme kerja anti-inflamasi dengan mengikat radikal bebas.

$$
\text { Apabila eritema menyebabkan }
$$
vasodilatasi dan pengeluaran mediatormediator peradangan, maka asam salisilat akan menghambat pengeluaran prostaglandin dan dapat menghambat pengeluaran histamin. Asam klorogenat, aukubin, baicalein, Bsitosterol dan catapol akan menghambat pengeluaran Interleukin (IL-1B, IL-2, IL-6) dan TNF- $\alpha$ karena peningkatan permeabilitas vaskuler dipicu oleh mediator peradangan yaitu TNF- $\alpha$ dan interleukin yang mana mediator tersebut dikeluarkan oleh sel makrofag untuk merangsang respon imun dapatan. Untuk tannin dan asam askorbat menghambat dengan cara mengikat radikal bebas agar radikal bebas tidak terikat dengan membran sel, sehingga sel tidak rusak dan tidak menimbulkan respon inflamasi dan juga dapat menurunkan permeabilitas vaskuler.

\section{KESIMPULAN DAN SARAN}

Penelitian tentang efek anti-inflamasi ekstrak daun sendok (Plantago major L.) yang diperoleh dari penyeduhan serbuk daun sendok dengan dosis $50 \mathrm{mg} / \mathrm{kg}$ dengan alat modifikasi UV 04-08 ini dapat menghambat eritema yang terjadi pada marmut, pernyataan ini berdasarkan pada hasil gradasi eritema dan persentase perubahan luas area eritema. Untuk itu dapat disimpulkan bahwa ekstrak daun sendok memiliki efek anti-inflamasi, tetapi efek anti-inflamasi ekstrak daun sendok tidak sebaik efek anti-inflamasi antalgin (sebagai pembanding). Diharapkan dilakukan suatu percobaan pada hewan coba lain yang memiliki sistem metabolisme tubuh yang mirip dengan manusia seperti simpanse dan pada penelitian dengan hewan coba tikus putih betina didapatkan efek anti-inflamasi ekstrak daun sendok sama dengan efek anti-inflamasi antalgin, karena sensitivitas tiap hewan coba berbeda dan menggunakan parameterparameter inflamasi yang lain

\section{UCAPAN TERIMA KASIH}

Ucapan terima kasih diberikan semua pihak yang membantu dalam penyelesaian jurnal ini.

\section{DAFTAR PUSTAKA}

Aherne S.A. dkk, 2007, Immodulatory Effects of $\boldsymbol{\beta}$-Sitosterol on Human Jurkat $\boldsymbol{T}$ cells, P-011, Planta Medica, p. 827

Anief, Formulasi Obat Topikal dengan Dasar Penyakit Kulit, p. 2-8

Arrington, Introductory Laboratory Animal Science, p. 82, 85, 131, 161

Barata Widjaja, The Journal of The Indonesian Medial Association, p. 223-227

Bullok R.R, 2002, Essential Tradisional Chinese Medicine, Caxton Publishing Group Ltd, London, p. 12-14 
EFEK EKSTRAK DAUN SENDOK (Plantago major L.) TERHADAP ERITEMA PADA MARMUT PUTIH BETINA (Guinea pig) OLEH RADIASI ALAT MODIFIKASI UV 04-08

Calixto J.B. dkk, 2004, Anti Inflammatory Compounds of Plant Origin Part II. Modulation of Pro Inflammatory Cytokines, Chemokins and Adhesion Molecules, Planta Medica, p. 93-100.

Collins R., Pavlik K, 2005, Classification of Skin Burns, Nucleus Medical Art, Inc, (http://catalognucleosine.com/display monograph.php) diakses 3 September 2007

Depkes RI, 1979, Farmakope Indonesia, Edisi IV, p. 12-13

Depkes RI, 1999, Materia Medika Indonesia, Jilid II, p. 95-96

Depkes RI, 1999, Sediaan Galenik, p. 5-12

Depkes RI, 1999, Pemanfaatan Tanaman Obat, edisi III, p. 79

Depkes RI, Penapisan Farmakologi Pengujian Fitokimia dan Pengujian Klinik, Pengembangan dan Pemanfaatan Obat Bahan Alam, p. 43-45.

Djuanda A., Ilmu Penyakit Kulit dan Kelamin, Edisi 2, Penerbit Fakultas Kedokteran UI, p. 3-8.

Essential Day Spa and Skin Store, Skin Anatomy and Physiology, (http://www.essentialdayspa.com) diakses 3 September 2007.

Gan G.S., 2003, Farmakologi dan Terapi, Edisi 5, Cetak Ulang, Bagian Farmakologi Fakultas kedokteran Universitas Indonesia, Jakarta, p. 208 dan p. 183-186, 194-195.

Guyton AC dan Hell Je, 2000, Textbook of Medical Physiology, $10^{\text {th }}$ edition, WB. Saunders Company, Philadelpia

Harber LC., Photosensitivity Disease, p. 84

Houglum J.E. Ph.D. dkk, 2004, Principles of Pharmacology for Athletic Trainers, Slack, p. 135-150 http://jacksite.wordpress.com/2007/08/10/obat -herbal-daun-sendok/ diakses 8 Oktober 2007.

Kalant, Roschlau, 1989, Principles of Medial Pharmacology, Fifth Edition, Philadelphia, p. 30-33.

Katzung, BG., 2005, Farmakologi Dasar dan Klinik, Edisi Delapan, EGC, Jakarta, p. 457, 582-583.

Kumar dan Robbins, 2000, Buku Ajar Patologi I, Penerbit Buku Kedokteran EGC, Jakarta, p. 41-42.

Laurence and Bacharch, Evaluation of Drug Activities Pharmacokinetics, Volume I, p. 85, 161.

Lehne R.H. Ph.D, 2004, Pharmacology for Nursing Care, Sixth Edition, Saunders, p. 809-817

Mitchell a. William, 2007, Plant Medicine in Practice, Churchill, Livingstore

Mitsui T, 2000, New Cosmetics Science Elsevier Science, p. 32-36.

Martindale The Extra Pharmacopoeia, Edisi 34, p. 273.

Okumura Y., Yamauchi H., dkk, 2004. Phototoxicity Study of a Ketoprofen Poultice in Guinea Pigs, p.

Price A. Sylvia, Wilson M. Lorraine, 2000, Patofisiologi Konsep Klinis ProsesProses Penyakit, Edisi Empat, Buku 1, Penerbit Buku Kedokteran EGC, p. 37, 42.

Raharjo, Tan HT, 1991, Obat-Obat penting, Khasiat, Penggunaan dan Efek-Efek Sampingnya, Edisi 4, Cetakan Kedua, 653-659, 663.

Rarnsworth R.N., Sara B.N., 1995, Thai Medisinal Plant Katha Co., Thailand, 3-4.

Rang HP., Dale MM, 2000, Pharmacology, Second Edition, London, 243-293. 
Roudabosh RI, Comparative Acute Effects of Some Chemicals on The Skin of Rabbits and Gulmea Pias Toxicol APPL Pharmacol, p. 559-565.

Schefler W.C., Statistika untuk Biologi Farmasi Kedokteran dan Ilmu yang Bertautan, p. 126-145.

Smith, John B, 1998, Pemeliharaan, Pembiakan dan Penggunaan Hewan Percobaan di Daerah Tropis, p. 37-38.

Umbach, Cosmetics and Toiletries Development Production and Use, $\mathrm{p}$. 97-99.

Underwood, J.C.E, 2000, Patologi Umum dan Sistematik, Editor, Edisi Bahasa Indonesia oleh Prof. Dr. Sarjadi, dr., PsPA, Edisi Kedua, Penerbit Buku Kedokteran EGC., 232-239.
Wagner H., 1996, Plant Drug Analysis, Second Edition, Springer, p. 76,80

Wijaya H., 1994, Tanaman Berkhasiat Obat di Indonesia, Jilid III, Penerbit: Kartini, p. 77-78.

World Health Organization Regional Publications Western Pacific Series No. 19, 1998, Medisinal Plants in The South Pacific, 149.

$\underline{\text { www.sehatsemua.logspot.com }}$

Wuryaningsih L.E, 2007, Uji Farmakologik pada Hewan,

Yamasaki, Yamasaki Lab. Plant Photo Gallery, (http://pharm1pharmazie.unigreifswald.de/syst ematic/7bilder/yamasaki/yamas606.jpg) diakses 3 September 2007. 